\author{
MAREK KUŹMICKI \\ Państwowa Szkoła Wyższa im. Papieża Jana Pawła II w Białej Podlaskiej, Polska - Pope John Paul II State \\ School of Higher Education in Biała Podlaska, Poland
}

\title{
Pożądane zmiany w otoczeniu międzynarodowym a rozwój przedsiębiorstw świadczących usługi noclegowe w województwie lubelskim
}

\section{Desirable Changes in the International Environment and the Development of Enterprises Providing Accommodation Services in the Lubelskie Voivodeship (Poland)}

Streszczenie: Celem niniejszego artykułu jest określenie na podstawie opinii właścicieli całorocznych obiektów noclegowych, jakie zmiany w otoczeniu międzynarodowym stworzyłyby dogodniejsze warunki rozwoju tego typu przedsiębiorstw. Ocena sytuacji została dokonana na podstawie badań własnych przeprowadzonych w kwietniu i maju 2018 r. metodą CATI na próbie 110 podmiotów działających na terenie województwa lubelskiego. Badania pokazały, że prawie co piąty badany przedsiębiorca widział bardzo dużą potrzebę zmian w uwzględnionych w nich obszarach otoczenia międzynarodowego. Jednocześnie co trzeci uczestnik badania nie widział takiej potrzeby wcale. Większą potrzebę zmian odczuwali przedsiębiorcy z gmin miejskich. Mniejsze, zbliżone potrzeby w tym względzie zadeklarowali respondenci z gmin wiejskich i miejsko-wiejskich. Choć moc sprawcza przedsiębiorców dotycząca zmian w otoczeniu międzynarodowym jest marginalna, ważne jest, aby mieli oni swoje wizje kształtowania uwarunkowań rozwoju przedsiębiorczości. Powinni je tworzyć i głośno o nich mówić.

\begin{abstract}
The aim of the article is to determine the desired changes in the international environment which, according to owners of year-round accommodation facilities, would create more favourable conditions for the development of enterprises providing accommodation services. The situation has been assessed based on the author's own research conducted in April and May 2018 using the CATI method on a sample of 110 entities operating in the Lubelskie Voivodeship. Roughly every fifth entrepreneur can see a great need to change the international environment in the areas included in the study. At the same time, every third participant of the research does not see any such need at all. A greater need for changes is felt by entrepreneurs from urban communes. Respondents from rural and urban-rural communes declare smaller but similar needs in this regard. Although entrepreneurs' causative power related to the changes in the international environment is marginal, it is important that they should have their own visions of how to shape the conditions for the development of entrepreneurship. They ought to create these conditions and speak about them loudly.
\end{abstract}


Słowa kluczowe: otoczenie międzynarodowe; przedsiębiorstwa świadczące usługi noclegowe; rozwój

Keywords: development; enterprises providing accommodation services; international environment

Otrzymano: 26 maja 2020

Received: 26 May 2020

Zaakceptowano: 30 lipca 2020

Accepted: 30 July 2020

\section{Sugerowana cytacja/Suggested citation:}

Kuźmicki, M. (2020). Pożądane zmiany w otoczeniu międzynarodowym a rozwój przedsiębiorstw świadczących usługi noclegowe w województwie lubelskim. Przedsiębiorczość - Edukacja [Entrepreneurship - Education], 16(2), 304-317. doi: 10.24917/20833296.162.24

\section{Wstęp}

Zgodnie $\mathrm{z}$ teorią organizacji i zarządzania, przedsiębiorstwo ma charakter otwarty. Współdziała ono ze światem zewnętrznym i utrzymuje różne związki ze swoim otoczeniem (Wolański, 2013: 42). Otoczenie przedsiębiorstwa można określić jako „ogół aktorów i sił, które w sposób bezpośredni lub pośredni oddziałują na jego zdolność do zyskownego zaspokajania potrzeb docelowych klientów” (Kotler, Armstrong, 1989: 54). Według M. Bednarczyk, otoczenie przedsiębiorstwa to „wszystko to, co nie należy do niego samego, a posiada wymiar czasoprzestrzenny, wywiera lub może wywierać na nie wpływ lub na co przedsiębiorstwo oddziałuje obecnie lub będzie oddziaływać w przyszłości” (Bednarczyk, 1996: 21). Z kolei J. Penc za otoczenie przedsiębiorstwa uważa „całokształt zjawisk, procesów i instytucji kształtujących jego stosunki wymienne, możliwości sprzedaży produktów, zakresy działania i perspektywy rozwojowe" (Penc, 2003: 14). Opisywane pojęcie można zdefiniować także jako „zespół wszystkich czynników wpływających na przetrwanie i rozwój przedsiębiorstwa” (Nowakowski, 2000: 22). Powyższe definicje akcentują istotną rolę otoczenia w tworzeniu uwarunkowań funkcjonowania przedsiębiorstw na rynku. G. Nizard wskazuje, że otoczenie to także miejsce podejmowania istotnych decyzji, narzucających organizacji ograniczenia i kształtujących jej przyszłość (Nizard, 1998: 17).

W literaturze dokonano klasyfikacji rodzajów otoczenia przedsiębiorstwa według różnych kryteriów. Jednym $\mathrm{z}$ istotniejszych $\mathrm{z}$ nich jest siła oddziaływania otoczenia przedsiębiorstwa i częstotliwość jego interakcji z organizacją. Biorąc to kryterium pod uwagę, otoczenie przedsiębiorstwa dzieli się na makrootoczenie (otoczenie dalsze) oraz mikrootoczenie (otoczenie bliższe), zwane także otoczeniem konkurencyjnym (Zygmunt, A., Zygmunt, J., 2016: 15). Elementy makro- i mikrootoczenia przedsiębiorstwa przedstawiono w tabeli 1.

W niniejszym artykule skoncentrowano się na otoczeniu międzynarodowym przedsiębiorstwa. D.A. Bali i W.H. McCulloch za otoczenie międzynarodowe uznają układ współdziałania między czynnikami występującymi w otoczeniu krajowym i zagranicznym a czynnikami znajdującymi się w otoczeniu zewnętrznym dla danego kraju (Bali, McCulloch, 1990: 15-17). Jego elementy zaprezentowano na rycinie 1. 
Tabela 1. Elementy otoczenia bliższego i dalszego przedsiębiorstwa

\begin{tabular}{|c|c|}
\hline $\begin{array}{c}\text { Elementy otoczenia bliższego } \\
\text { przedsiębiorstwa }\end{array}$ & $\begin{array}{c}\text { Elementy otoczenia dalszego } \\
\text { przedsiębiorstwa }\end{array}$ \\
\hline $\begin{array}{l}\text { - klienci; odbiorcy produktów, towarów i usług } \\
\text { - dostawcy i usługodawcy, w tym instytucje } \\
\text { obsługi finansowej i rynku kapitałowego } \\
\text { - konkurenci, kooperenci } \\
\text { - sojusznicy strategiczni }\end{array}$ & $\begin{array}{l}\text { - otoczenie ekonomiczne } \\
\text { - otoczenie techniczno-technologiczne } \\
\text { - otoczenie edukacyjne } \\
\text { - otoczenie polityczne } \\
\text { - otoczenie formalno-prawne }\end{array}$ \\
\hline $\begin{array}{l}\text { - regulatorzy, w tym instytucje administracji } \\
\text { publicznej } \\
\text { - lokalny rynek pracy } \\
\text { - lokalne czynniki społeczne } \\
\text { - w niektórych typologiach do elementów } \\
\text { otoczenia bliższego zalicza się również } \\
\text { akcjonariuszy i właścicieli organizacji }\end{array}$ & $\begin{array}{l}\text { - otoczenie demograficzno-społeczne } \\
\text { - otoczenie kulturowe } \\
\text { - otoczenie naturalne } \\
\text { - otoczenie międzynarodowe }\end{array}$ \\
\hline
\end{tabular}

Źródło: na podstawie: Adamik, Matejun (2012: 61-63).

Rycina 1. Elementy otoczenia międzynarodowego i ich związek z przedsiębiorstwem

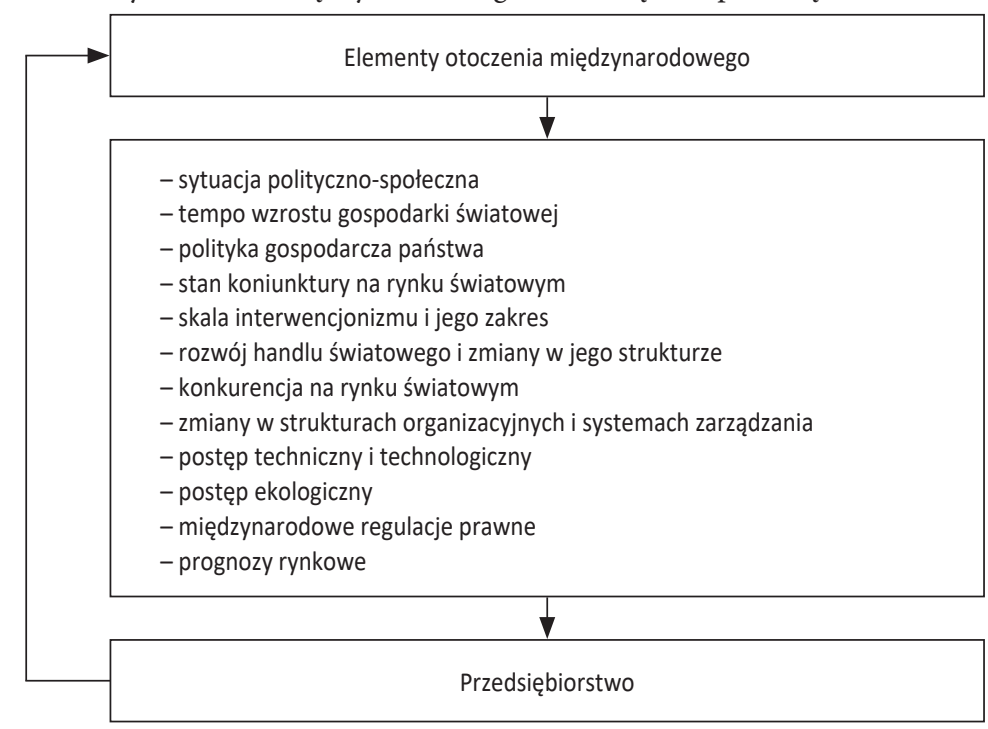

Źródło: Żurek (2003: 58)

Otoczenie, w którym działa przedsiębiorstwo, ma charakter zmienny, burzliwy i dynamiczny (Ansoff, 1995: 58). Stanowi ono dla podmiotu gospodarczego główne źródło szans i zagrożeń, a jednocześnie stawia wymogi i ograniczenia (Kowalczuk, 2015: 38). Dokładna analiza czynników otoczenia pomaga we właściwej alokacji zasobów przedsiębiorstwa i jest podstawą wszelkich procesów decyzyjnych w firmie oraz uzyskiwania przez przedsiębiorstwo określonej pozycji na rynku (Gołembski, 2007: 66). Przedsiębiorstwa $\mathrm{w}$ warunkach zmieniającego się dynamicznie otoczenia powinny szybko reagować i dostosowywać się do nowej sytuacji. Niestety, w ujęciu międzynarodowym, a nawet globalnym wzrasta liczba sytuacji kryzysowych, które bezpośrednio wpływają na sytuację podmiotów gospodarujących (Mekinc, Cvikl, 2013: 41). 
Celem niniejszego artykułu jest określenie, jakie zmiany w otoczeniu międzynarodowym stworzyłyby, zdaniem właścicieli całorocznych obiektów noclegowych funkcjonujących w województwie lubelskim, dogodniejsze warunki rozwoju przedsiębiorstw świadczących usługi noclegowe ${ }^{1}$. Cel ten został zrealizowany na podstawie identyfikacji oczekiwań właścicieli badanych podmiotów dotyczących zmian w poszczególnych wymiarach otoczenia międzynarodowego.

Artykuł jest próbą odpowiedzi na pytanie: Czy i w jakim stopniu czynniki otoczenia międzynarodowego powinny ulec zmianie, aby w nowym kształcie bardziej sprzyjać rozwojowi przedsiębiorstw noclegowych w województwie lubelskim? Podjęta tematyka dotyczy obszaru otoczenia przedsiębiorstw, które jest rzadko przedmiotem zainteresowania badaczy, co stanowi wartość dodaną opracowania. Większość publikacji w tym zakresie koncentruje się na otoczeniu lokalnym i krajowym. Tymczasem rola otoczenia międzynarodowego w kształtowaniu warunków rozwoju działalności gospodarczej wzrasta. W tej sytuacji warto skoncentrować wysiłki badawcze na jego dokładniejszym rozpoznaniu.

\section{Otoczenie międzynarodowe - wybrane zagadnienia teoretyczne}

Istotnym elementem otoczenia międzynarodowego, wpływającym na warunki prowadzenia działalności gospodarczej, jest istniejąca koniunktura gospodarcza. Termin „koniunktura” wywodzi się od łacińskiego słowa coniunctio, które oznacza ‘łącznie’ rozumiane jako splot warunków wywierających znaczny (zazwyczaj dodatni) wpływ na sytuację, położenie, ogólny stan czegoś. W odniesieniu do zjawisk ekonomicznych termin ten zastosowano dopiero w XIX w. Koniunktura gospodarcza to wszelkie zmiany aktywności gospodarczej przejawiające się w zmianach podstawowych wskaźników ekonomicznych, określających kondycję gospodarki, wśród których należy wymienić przede wszystkim $\mathrm{PKB}, \mathrm{PNB}$, inwestycje, konsumpcję, wskaźniki bezrobocia oraz inflację. Koniunktura gospodarcza odzwierciedla cykliczny przebieg procesu gospodarowania i odnosi się zarówno do stanu, jak i do dynamiki zjawisk oraz procesów gospodarczych (Koniunktura gospodarcza).

Na sytuację przedsiębiorstw świadczących usługi turystyczne wpływają stosunki międzynarodowe kraju. A. Polus opisywał stosunki międzynarodowe jako „relacje, które przekraczają granice państw” (Polus, 2018: 45). Stosunki międzynarodowe można rozumieć jako transgraniczne interakcje podmiotów polityki w środowisku poliarchicznym ${ }^{2}$ (Łoś-Nowak, 1997: 12). Według F.R. Pfetscha, stosunki międzynarodowe to „całość transgranicznych relacji między aktorami polityki” (Pfetsch, 1994: 29). Można przyjąć za B. Molo, że „stosunki międzynarodowe są ogółem wszystkich rodzajów aktywności podmiotów tych stosunków wykraczającej poza granice państw”. Każda taka aktywność indukuje reakcje zarówno w innych państwach, jak i w środowisku międzynarodowym (Molo, 2018: 15).

\footnotetext{
${ }^{1}$ Pod pojęciem rozwoju przedsiębiorstw świadczących usługi noclegowe rozumie się wszelkiego rodzaju zmiany dokonujące się $\mathrm{w}$ przedsiębiorstwach, powodujące poprawę efektywności ich działania i pozycji rynkowej. Za mierniki rozwoju przedsiębiorstw turystycznych przyjęto: uzyskiwany wynik finansowy, wskaźnik rentowności sprzedaży, dynamikę przychodów ze sprzedaży, płynność finansową, wartość posiadanych aktywów, poziom zatrudnienia i aktywność inwestycyjną.

${ }^{2}$ Poliarchizm jest rozumiany jako „rządy wielu podmiotów”; Łoś-Nowak (1997: 12).
} 
Elementem otoczenia międzynarodowego jest także polityka gospodarcza państwa. W literaturze przedmiotu istnieje wiele jej definicji. Polityka gospodarcza występuje jako synonim polityki ekonomicznej (Jarmołowicz, Knapińska, 2005: 78). Według E. Taylora, polityka gospodarcza to sztuka celowego działania gospodarczego, podejmowana głównie z punktu widzenia celów społecznych i państwowych (Taylor, 1947: 38-39). Polega ona na świadomym oddziaływaniu prowadzących ją organów na zjawiska gospodarcze za pomocą określonych narzędzi służących do osiągnięcia założonych celów (Kaja, 2007: 9-11). W opinii R. Michalskiego polityka gospodarcza to działalność władz ekonomicznych danego kraju polegająca na celowym i świadomym kształtowaniu wyników gospodarczych zgodnie z wyznawanym systemem norm i wartości oraz w ramach istniejących ograniczeń strukturalnych i modelowych (Michalski, 1990: 11). Jednym z podstawowych celów ekonomicznych polityki gospodarczej jest rozwój przedsiębiorczości, co stanowi główny obszar zainteresowań autora.

Warunki funkcjonowania przedsiębiorstw turystycznych uzależnione są od polityki turystycznej realizowanej przez państwo. W przypadku Polski jest ona prowadzona także w ramach struktur międzynarodowych, szczególnie Unii Europejskiej (UE) i Organizacji Współpracy Gospodarczej i Rozwoju (Organisation for Economic Cooperation and Development - OECD). „Polityka turystyczna jest to działalność polegająca na określaniu celów ekonomicznych, politycznych, społecznych i kulturalnych związanych z rozwojem turystyki, uzyskiwaniu wszechstronnych pozytywnych efektów wynikających z istnienia popytu i podaży, dążeniu do zaspokojenia potrzeb społecznych w zakresie uprawiania turystyki” (Wodejko, 1998: 170). „Głównym zadaniem polityki turystycznej powinno być kształtowanie optymalnych rozmiarów i struktury ruchu turystycznego przy zastosowaniu praw ekonomicznych w sferze gospodarki turystycznej, koordynacja rozwoju turystyki z uwzględnieniem jej funkcji i różnorodności jej związków z innymi sferami funkcjonowania kraju" (Panasiuk, 2016: 115).

Na sytuację polskich przedsiębiorców wpływa przynależność Polski do struktur UE, która szczególną wagę przykłada do rozwijania przedsiębiorczości i konkurencyjności. Priorytetowo traktowane są w niej przedsiębiorstwa małe i średnie - to one mogą liczyć na relatywnie największą pomoc (MŚP i fundusze Unii Europejskiej..., 2020). Środki z budżetu UE przyznane Polsce na dofinansowanie w ramach funduszy strukturalnych w latach 2014-2020 są o 10 mld euro większe niż w perspektywie finansowej 2007-2013. Ich wysokość to 82,5 mld euro. W latach 2014-2020 trafiały one do beneficjentów za pośrednictwem pięciu programów operacyjnych wdrażanych na szczeblu centralnym, szesnastu regionalnych programów operacyjnych i jednego programu ponadregionalnego (Fundusze unijne dla przedsiębiorstw...). Polscy przedsiębiorcy w perspektywie finansowej 20142020 mogli pozyskać środki w ramach wsparcia bezzwrotnego (dotacji) oraz zwrotnego (pożyczek). Wsparcie to pochodziło z trzech głównych źródeł: Programu Operacyjnego Inteligentny Rozwój, Programu Operacyjnego Polska Wschodnia oraz programów regionalnych. Przedsiębiorcy z terenów wiejskich mogli aplikować o fundusze z Programu Rozwoju Obszarów Wiejskich (Piwowarczyk, 2017: 333).

Istotne znaczenie dla rozwoju przedsiębiorstw świadczących usługi noclegowe $\mathrm{w}$ danym regionie ma popyt na podstawowe usługi turystyczne. Jest on uzależniony od wielkości krajowego i międzynarodowego ruchu turystycznego. Międzynarodowa Akademia Turystyki w Monte Carlo przez ruch turystyczny rozumie „podróże podejmowane dla przyjemności, wypoczynku lub leczenia - pieszo lub jakimkolwiek środkiem 
komunikacji” (Pytel, Szromek, 2012: 109). Inaczej można ten termin ująć jako przestrzenne przemieszczanie się ludzi, które jest związane $\mathrm{z}$ dobrowolną i czasową zmianą miejsca pobytu, środowiska i rytmu życia (Duda-Gromada, 2009: 87). Podstawowymi miernikami wykorzystywanymi do charakterystyki ruchu turystycznego są: wskaźnik Deferta, wyrażony liczbą turystów korzystających z noclegów przypadającą na kilometr kwadratowy powierzchni całkowitej, oraz wskaźnik Schneidera, wyrażony liczbą turystów korzystających z noclegów przypadającą na tysiąc mieszkańców stałych (Lijewski, Mikułowski, Wyrzykowski, 2002: 23-25).

Większość analiz dotyczących uwarunkowań rozwoju przedsiębiorstw turystycznych wynikających z makrootoczenia opiera się na metodzie PEST uwzględniającej czynniki polityczne, ekonomiczne, społeczno-kulturowe i technologiczne. Przykładem może być analiza otoczenia dalszego sektora turystyki dokonana przez R. Sijabat (Sijabat, 2019). Niektóre analizy wpływu makrootoczenia na podmioty rynku turystycznego uwzględniają uwarunkowania naturalne i ekologiczne (Barkauskas, Barkauskiene, Jasinskas, 2015; Kulieshova, 2014). Można odnaleźć także takie, które odnoszą się do uwarunkowań demograficznych i kulturowych (Kucharenko, 2017). Badania podjęte przez autora niniejszego artykułu, dotyczące wpływu otoczenia międzynarodowego na rozwój przedsiębiorstw noclegowych, pozwalają na rozpoznanie pożądanych uwarunkowań rozwoju podmiotów gospodarczych wynikających z obszarów rzadko poddawanych analizie, także w skali międzynarodowej.

\section{Metodyka badań}

Województwo lubelskie jest zaliczane do najbiedniejszych i najbardziej zapóźnionych pod względem rozwoju gospodarczego regionów w Europie. Władze samorządowe szansy na rozwój upatrują w intensyfikacji ruchu turystycznego (Kobyłka, Mazurek-Kusiak, 2017: 102). Liczba turystów odwiedzających województwo lubelskie każdego roku wzrasta. W 2018 r. było to ponad 2 mln osób, a w 2019 r. liczba ta wzrosła o blisko 5 tys. osób. Wzrasta też liczba turystów zagranicznych - ich udział w ogólnej liczbie turystów w 2019 r. był zbliżony do 20\% (Badania ruchu turystycznego...).

Warunkiem rozwoju turystyki na terenie województwa lubelskiego jest tworzenie bazy turystycznej zaspakajającej pod względem ilościowym i jakościowym oczekiwania turystów. Jej najistotniejszym elementem jest baza noclegowa. W końcu lipca 2017 r. na terenie województwa lubelskiego funkcjonowało 445 turystycznych obiektów noclegowych. Stanowiło to $4,2 \%$ wszystkich obiektów w kraju. W porównaniu z rokiem poprzednim liczba tych obiektów zwiększyła się o 5,5\%. Liczba obiektów noclegowych całorocznych wzrosła o $8,2 \%$. Stanowiły one $65,2 \%$ wszystkich obiektów na terenie województwa lubelskiego. Analogiczny odsetek w skali kraju wynosił 68,4\% (Urząd Statystyczny w Lublinie, 2018).

Należy podkreślić, że ilościowy udział obiektów noclegowych zlokalizowanych na terenie województwa lubelskiego od lat kształtuje się na niskim poziomie w porównaniu z innymi województwami. Rozwój bazy noclegowej, tak ważny dla rozwoju regionu, w innych województwach zachodzi intensywniej. Zaistniała sytuacja zainspirowała autora niniejszego artykułu do przeprowadzenia badań, których wyniki mają walory poznawcze oraz praktyczne. Powinny one stać się przedmiotem przemyśleń i impulsem do działań krajowej i lokalnej administracji, odpowiedzialnej za tworzenie rozwiązań ułatwiających rozwój przedsiębiorstw, także tych działających na rynku usług turystycznych. 
Na potrzeby opracowania w kwietniu i maju 2018 r. autor przeprowadził badania własne. Ich zakres podmiotowy stanowiły całoroczne turystyczne obiekty noclegowe działające na terenie województwa lubelskiego. Liczebność próby badawczej wyniosła 110 podmiotów. Struktura próby badawczej została przedstawiona w tabeli 2 .

Tabela 2. Struktura próby badawczej

\begin{tabular}{|c|c|c|c|c|c|}
\hline Typ obiektu & $\%$ & $\begin{array}{c}\text { Forma } \\
\text { organizacyjno-prawna }\end{array}$ & $\%$ & $\begin{array}{c}\text { Okres } \\
\text { funkcjonowania }\end{array}$ & $\%$ \\
\hline Inne obiekty hotelowe & 38,2 & \begin{tabular}{|l|} 
osoby fizyczne \\
prowadzące działalność \\
gospodarczą
\end{tabular} & 86,4 & dłużej niż 5 lat & 66,4 \\
\hline Hotele & 24,6 & spółki cywilne & 9,1 & $3-5$ lat & 21,8 \\
\hline $\begin{array}{l}\text { Pokoje gościnne } \\
\text { (kwatery prywatne) }\end{array}$ & 22,8 & jednostki budżetowe & 2,7 & 1 rok-3 lata & 11,8 \\
\hline Pensjonaty & 4,5 & spółki jawne & 0,9 & & \\
\hline Motele & 3,6 & \begin{tabular}{|l|}
$\begin{array}{l}\text { spółki z ograniczoną } \\
\text { odpowiedzialnością }\end{array}$ \\
\end{tabular} & 0,9 & & \\
\hline $\begin{array}{l}\text { Ośrodki szkoleniowo- } \\
\text {-wypoczynkowe }\end{array}$ & 2,7 & & & & \\
\hline $\begin{array}{l}\text { Zespoły } \\
\text { ogólnodostępnych } \\
\text { domków turystycznych }\end{array}$ & 1,8 & & & & \\
\hline Hostele & 0,9 & & & & \\
\hline Zakłady uzdrowiskowe & 0,9 & & & & \\
\hline
\end{tabular}

Źródło: badania własne

Do określenia struktury populacji generalnej z uwagi na typy całorocznych obiektów noclegowych przyjęto dane GUS-u, dostępne w internecie, w Banku Danych Lokalnych. Liczebność populacji generalnej wynosiła 290 podmiotów (stan na 31 lipca 2017 r.). Przy zaliczaniu jednostek do próby badawczej została zastosowana metoda doboru losowego, warstwowego. Warstwą był typ całorocznego obiektu noclegowego według typologii GUS. Liczebność jednostek w próbie badawczej w poszczególnych warstwach w powiatach była zależna od liczebności tych jednostek w populacji generalnej w tych samych powiatach. Po określeniu liczebności warstw na poziomie powiatów zaliczono jednostki do próby badawczej, losując konkretne obiekty do badań. Aktualny i kompletny operat stanowiła baza adresowa uzyskana z Wojewódzkiego Urzędu Statystycznego w Lublinie. Respondentami (jednostkami statystycznymi) byli właściciele przedsiębiorstw świadczących całoroczne usługi noclegowe - przedsiębiorcy. Zastosowana metoda doboru jednostek do próby badawczej oraz liczebność próby badawczej pozwoliły stworzyć reprezentatywną próbę badawczą względem badanej populacji. Do określenia struktury próby badawczej wykorzystano powszechnie wykorzystywaną w analizach rynku turystycznego typologię obiektów noclegowych przyjętą przez GUS.

Do przeprowadzenia badań wykorzystano metodę CATI (ang. computer-assisted telephone interviewing - wspomagany komputerowo wywiad telefoniczny). Wybór tej metody wynikał z jej zalet - umożliwia ona realizację badań w sposób rzetelny i dokładny. CATI charakteryzuje się krótkim czasem przeprowadzania badań, wysoką jakością otrzymywanych wyników, a także niższymi kosztami w porównaniu z badaniami terenowymi. 
W czasie wywiadu poproszono respondentów o określenie potrzeby zmiany czynników, które przyczyniają się do rozwoju ich przedsiębiorstwa. Istniała możliwość udzielenia odpowiedzi w skali 1-5, gdzie 1 oznaczało brak potrzeby zmiany, 5 - bardzo dużą potrzebę zmiany. Ocenie poddano najważniejsze w opinii autora uwarunkowania otoczenia międzynarodowego, wpływające na sytuację przedsiębiorstw świadczących usługi noclegowe, tj.: stan koniunktury na rynku światowym, stosunki międzynarodowe Polski, politykę gospodarczą UE, politykę turystyczną UE i OECD, ofertę programów pomocowych UE dla przedsiębiorców, prognozy rozwoju międzynarodowego ruchu turystycznego.

W celu przedstawienia wyników badań w ujęciu statystycznym na podstawie uzyskanych odpowiedzi obliczono wskaźniki struktury, mediany i mody. Do określenia różnic istotnych statystycznie między odpowiedziami respondentów działających w różnych typach gmin wykorzystano test Kruskala-Wallisa. Test ten został wybrany z uwagi na fakt, iż wszystkie zmienne zależne mierzone były w trakcie badań w skali porządkowej. Obliczenia zostały dokonane przy pomocy pakietu Statistica 10.0. Jako poziom istotności wybrano 0,05 .

\section{Wyniki badań}

W czasie badań respondenci ocenili potrzebę zmian $\mathrm{w}$ otoczeniu międzynarodowym w kontekście tworzenia uwarunkowań ułatwiających rozwój podmiotów gospodarczych. Do pomiaru wykorzystano pięciostopniową skalę porządkową, w której, jak zostało to powiedziane wcześniej, ocena 1 oznaczała brak potrzeby zmiany, 5 - bardzo dużą potrzebę zmiany. Wyniki badań zostały przedstawione na rycinie 2 .

Rycina 2. Potrzeba zmiany otoczenia międzynarodowego wpływającego na rozwój przedsiębiorstw świadczących usługi noclegowe - struktura odpowiedzi (\%)

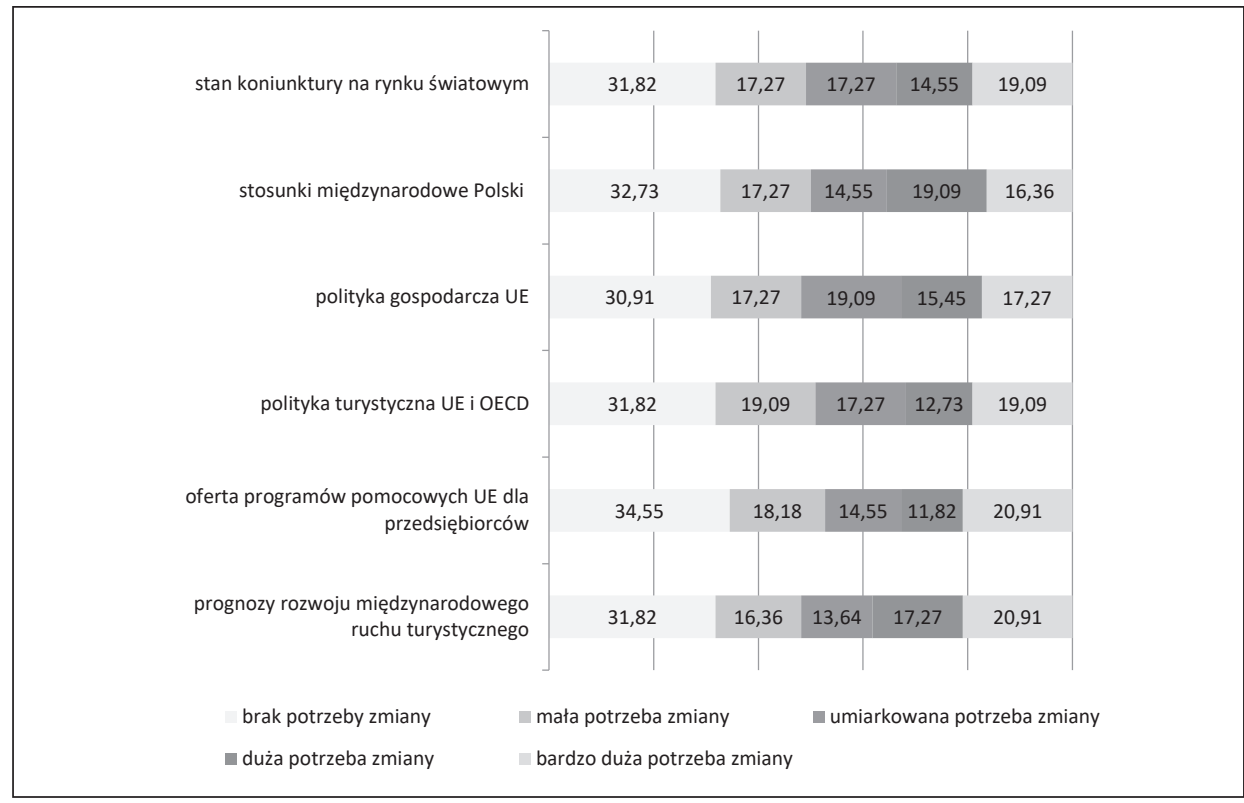

Źródło: badania własne 
Mniej więcej co piąty badany przedsiębiorca widział bardzo dużą potrzebę zmiany w obszarach otoczenia międzynarodowego uwzględnionych w badaniach. Jednocześnie co trzeci uczestnik badania nie widział takiej potrzeby wcale. Tak wysoki udział procentowy respondentów z tej grupy może świadczyć o niskim poziomie świadomości części badanych przedsiębiorców na temat wpływu analizowanych czynników zewnętrznych na sytuację przedsiębiorstw świadczących usługi noclegowe. Wydaje się, że znaczna grupa przedsiębiorców myśli oraz działa lokalnie i nie widzi związku między sytuacją swojej firmy a uwarunkowaniami międzynarodowymi makrootoczenia.

Mediana dla większości badanych czynników, tj. stanu koniunktury na rynku światowym, stosunków międzynarodowych Polski, polityki gospodarczej UE i prognoz rozwoju międzynarodowego ruchu turystycznego, wynosi 3 - umiarkowana potrzeba zmiany. Połowa wyników badań ma niższą lub wyższą wartość w skali 1-5. W przypadku polityki turystycznej UE oraz OECD, jak również oferty programów pomocowych UE dla przedsiębiorców, średnia wartość wynosi 2 - mała potrzeba zmiany. Połowa wyników badań ma wyższą wartość. Mediany dla analizowanych czynników nie są jednakowe w różnych typach gmin. W przypadku gmin wiejskich i miejsko-wiejskich przyjmują wartość 2 , a w gminach miejskich - wartość 3. Najczęściej wśród odpowiedzi pojawiała się ocena 1 - brak potrzeby zmiany (moda wynosi 1 ). Wyniki badań przedstawiono w tabeli 3.

Tabela 3. Potrzeba zmiany otoczenia międzynarodowego wpływającego na rozwój przedsiębiorstw świadczących usługi noclegowe - mediana i moda*

\begin{tabular}{|c|c|c|c|c|c|c|c|c|}
\hline \multirow{2}{*}{$\begin{array}{l}\text { Czynniki otoczenia międzynarodowego } \\
\text { wpływające na przedsiębiorstwa } \\
\text { świadczące usługi noclegowe }\end{array}$} & \multicolumn{2}{|c|}{$\begin{array}{l}\text { Gminy } \\
\text { miejskie }\end{array}$} & \multicolumn{2}{|c|}{$\begin{array}{l}\text { Gminy } \\
\text { miejsko- } \\
\text {-wiejskie }\end{array}$} & \multicolumn{2}{|c|}{$\begin{array}{l}\text { Gminy } \\
\text { wiejskie }\end{array}$} & \multicolumn{2}{|c|}{ Ogół } \\
\hline & 急导 & 章高 & 莺 & 粂 & 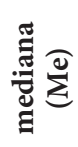 & 营 & 芯 & 吾 \\
\hline Stan koniunktury na rynku światowym & 3 & 1 & 2 & 1 & 2 & 1 & 3 & 1 \\
\hline Stosunki międzynarodowe Polski & 3 & 1 & 2 & 1 & 2 & 1 & 3 & 1 \\
\hline Polityka gospodarcza UE & 3 & brak & 2 & 1 & 2 & 1 & 3 & 1 \\
\hline Polityka turystyczna UE i OECD & 3 & 1 & 2 & 1 & 2 & 1 & 2 & 1 \\
\hline $\begin{array}{l}\text { Oferta programów pomocowych UE } \\
\text { dla przedsiębiorców }\end{array}$ & 3 & 1 & 2 & 1 & 2 & 1 & 2 & 1 \\
\hline $\begin{array}{l}\text { Prognozy rozwoju międzynarodowego } \\
\text { ruchu turystycznego }\end{array}$ & 3 & 1 & 2 & 1 & 2 & 1 & 3 & 1 \\
\hline
\end{tabular}

* Wyniki odpowiadają wartościom w skali 1-5, gdzie: 1 - brak potrzeby zmiany, 2 - mała potrzeba zmiany, 3 - umiarkowana potrzeba zmiany, 4 - duża potrzeba zmiany, 5 - bardzo duża potrzeba zmiany

Źródło: badania własne

Analiza wyników badań pozwoliła określić zależności między dokonaną przez respondentów oceną potrzeb zmian otoczenia międzynarodowego a rodzajem gmin, w których badane przedsiębiorstwa funkcjonują. Zależności te zostały przedstawione w tabeli 4. 
Tabela 4. Wyniki testu Kruskala-Wallisa dla ocen potrzeby zmiany otoczenia międzynarodowego wpływającego na rozwój przedsiębiorstw świadczących usługi noclegowe

\begin{tabular}{|l|c|c|c|c|c|}
\hline \multicolumn{1}{|c|}{$\begin{array}{c}\text { Czynniki otoczenia } \\
\text { międzynarodowego } \\
\text { wpływające na } \\
\text { przedsiębiorstwa } \\
\text { świadczące usługi } \\
\text { noclegowe }\end{array}$} & \begin{tabular}{c}
$|c|$ \\
Sminy \\
\cline { 2 - 4 }
\end{tabular} & $\begin{array}{c}\text { Średnia wartość rang ocen } \\
\text { gminy } \\
\text { miejsko- } \\
\text { wiejskie }\end{array}$ & $\begin{array}{c}\text { 年miny } \\
\text { wiejskie }\end{array}$ & $\begin{array}{c}\text { Statystyka } \\
\text { testowa H }\end{array}$ & p-value \\
\hline $\begin{array}{l}\text { Stan koniunktury na rynku } \\
\text { światowym }\end{array}$ & 59,45 & 51,55 & 52,18 & 1,66 & 0,44 \\
\hline $\begin{array}{l}\text { Stosunki międzynarodowe } \\
\text { Polski }\end{array}$ & 59,63 & 51,89 & 51,36 & 1,82 & 0,40 \\
\hline Polityka gospodarcza UE & 60,52 & 50,97 & 50,66 & 2,67 & 0,26 \\
\hline $\begin{array}{l}\text { Polityka turystyczna UE } \\
\text { i OECD }\end{array}$ & 60,49 & 52,17 & 49,18 & 2,77 & 0,25 \\
\hline $\begin{array}{l}\text { Oferta programów } \\
\text { pomocowych UE dla } \\
\text { przedsiębiorców }\end{array}$ & 57,03 & 53,97 & 54,22 & 0,25 & 0,88 \\
\hline $\begin{array}{l}\text { Prognozy rozwoju } \\
\text { międzynarodowego ruchu } \\
\text { turystycznego }\end{array}$ & 59,57 & 52,75 & 50,40 & 1,84 & 0,40 \\
\hline
\end{tabular}

Źródło: opracowanie własne

Wyniki testu Kruskal-Wallisa nie potwierdziły hipotezy o występowaniu istotnych statystycznie różnic $\mathrm{w}$ ocenach dokonanych przez przedsiębiorców z różnych typów gmin. W każdym z przypadków poddanych analizie wartość p-value spełniała warunek p > 0,05. Należy zaznaczyć, że większą potrzebę zmian uwarunkowań rozwoju przedsiębiorczości wynikających z otoczenia międzynarodowego odczuwają przedsiębiorcy z gmin miejskich. Mniejsze, zbliżone potrzeby w tym względzie deklarują respondenci z gmin wiejskich i miejsko-wiejskich.

\section{Podsumowanie}

Przegląd wyników badań dotyczących determinant rozwoju przedsiębiorstw turystycznych wynikających z makrootoczenia pozwala zauważyć, że zdecydowana większość z nich koncentruje się na czynnikach ekonomicznych, polityczno-prawnych, kulturowych, społecznych, przyrodniczo-ekologicznych czy technologicznych. Przykładem mogą być badania zrealizowane przez A. Panasiuka dotyczące wpływu uwarunkowań otoczenia dalszego na działalność przedsiębiorstw turystycznych (Panasiuk, 2019: 16-19). Rzadko podejmowany jest wątek uwarunkowań międzynarodowych rozwoju podmiotów gospodarczych. Pojawiają się jedynie opracowania dotyczące wybranych zagadnień, np. przynależności Polski do organizacji międzynarodowych o charakterze politycznym i gospodarczym (Dziedzic, Skalska, 2012: 55), czy też akcentujące międzynarodowe uwarunkowania działalności na rynku turystycznym (Panasiuk, 2014: 163-164). Trudno natomiast w literaturze odnaleźć analizy badań rynkowych, które w sposób kompleksowy podejmowałyby zagadnienie uwarunkowań rozwoju przedsiębiorstw turystycznych wynikających z otoczenia międzynarodowego. Niniejszy artykuł koncentruje się na wspomnianej tematyce i tym samym uzupełnia istniejącą lukę. 
Z perspektywy przedsiębiorców istotne jest określenie „kształtu” otoczenia, w tym otoczenia międzynarodowego, które stwarzałoby sprzyjające warunki rozwoju ich podmiotów gospodarczych. Działanie to wiąże się z sugerowaniem zmian ułatwiających funkcjonowanie. Przedsiębiorcy posiadający pożądany obraz otoczenia swojej firmy mogą próbować wpływać na podmioty odpowiedzialne za kreowanie uwarunkowań prowadzenia działalności gospodarczej.

Znaczna część uczestników badania nie odczuwa potrzeby zmian w otoczeniu międzynarodowym. Osoby te prawdopodobnie nie widzą związku między uwarunkowaniami otoczenia międzynarodowego a położeniem swojego przedsiębiorstwa. Takie postrzeganie rzeczywistości jest błędne. Działania naprawcze powinny polegać na uświadamianiu przedsiębiorcom szans tkwiących $\mathrm{w}$ otoczeniu międzynarodowym przez edukację i działania promocyjne. Sposobem na realizację tego celu mogłoby być zorganizowanie przez organy rządowe odpowiedzialne za rozwój przedsiębiorczości i turystyki, w tym Departament Turystyki w Ministerstwie Rozwoju, akcji informacyjnej. Jest ona szczególnie potrzebna w przypadku respondentów działających na terenie gmin wiejskich i miejsko-wiejskich w województwie lubelskim. Podobne działania mógłby zainicjować Wydział Turystyki Dyrekcji Generalnej do spraw Przedsiębiorstw i Przemysłu w Komisji Europejskiej, który kształtuje i realizuje politykę turystyczną UE. Przedsięwzięcie wydaje się być uzasadnione, tym bardziej, że stoimy u progu nowej, unijnej perspektywy finansowej na lata 2021-2027.

Mniej więcej co trzeci badany przedsiębiorca chciał w momencie badania w dużym lub bardzo dużym stopniu zmienić stan koniunktury na rynku światowym, stosunki międzynarodowe Polski, politykę gospodarczą i turystyczną UE oraz OECD, ofertę programów pomocowych UE dla przedsiębiorców, a także prognozy rozwoju międzynarodowego ruchu turystycznego. Opinie respondentów z województwa lubelskiego wynikają zapewne z niezadowolenia $\mathrm{z}$ istniejącego stanu. Choć moc sprawcza przedsiębiorców dotycząca zmian w otoczeniu międzynarodowym jest marginalna, ważne jest, aby mieli oni swoje wizje kształtowania uwarunkowań rozwoju przedsiębiorczości. Powinni je tworzyć i głośno o nich mówić. Rząd odpowiedzialny za kreowanie polityki międzynarodowej oraz klimatu rozwoju przedsiębiorczości powinien się w ten głos wsłuchiwać i brać go pod uwagę, tworząc nowe lub modyfikując stare regulacje dotyczące prowadzenia działalności gospodarczej. Podobnie powinny czynić organizacje międzynarodowe, których Polska jest członkiem. W przypadku przedsiębiorców działających na rynku usług noclegowych za najważniejsze należy uznać UE i OECD. Ich programy pomocowe powinny być dopasowane do potrzeb potencjalnych beneficjentów - właścicieli obiektów noclegowych, a oni sami powinni być świadomi szans, jakie im są stwarzane.

Niniejszy artykuł nakreśla potrzebę dalszych badań dotyczących świadomości przedsiębiorców na temat wpływu na prowadzoną działalność gospodarczą uwarunkowań wynikających z otoczenia międzynarodowego. Przytoczone powyżej sugestie zostały sformułowane na podstawie wyników badań o charakterze regionalnym. Opierając się na nich, nie można formułować wniosków dotyczących wszystkich przedsiębiorstw świadczących usługi noclegowe w kraju. Ze względu na wagę podjętej problematyki istnieje potrzeba zwiększenia zakresu przestrzennego badań na teren całej Polski. Zasadne wydaje się także rozszerzenie zakresu przedmiotowego badań o uwarunkowania rozwoju przedsiębiorstw świadczących usługi noclegowe, wynikające z otoczenia ekonomicznego, polityczno-prawnego, społeczno-demograficznego, technologicznego i naturalnego. 
Literatura

References

Adamik, A., Matejun, M. (2012). Organizacja i jej miejsce w otoczeniu. W: A. Zakrzewska-Bielawska (red.), Podstawy zarzadzania. Warszawa: Wolters Kluwer, 61-63.

Ansoff, H.I. (1995). Zarządzanie strategiczne. Warszawa: PWE.

Badania ruchu turystycznego - Barometr Turystyczny Lublina i Lubelskie Regionalne Obserwatorium Turystyczne. (2020, 19 lipca). Pozyskano z: https://www.biostat.com.pl/badania-ruchu-turystycznego.php

Bali, D.A., McCulloch, W.H. (1990). International Business. Introduction and Essentials. Boston: HomeWood.

Barkauskas, V., Barkauskiene, K., Jasinskas, E. (2015). Analysis of macro environmental factors influencing the development of rural tourism: Lithuanian case. Procedia - Social and Behavioral Sciences, 213, 167-172.

Bednarczyk, M. (1996). Otoczenie i przedsiębiorczość w zarządzaniu strategicznym organizacją gospodarczą. Zeszyty Naukowe Akademii Ekonomicznej w Krakowie. Seria Specjalna: Monografie, 128.

Duda-Gromada, K. (2009). Charakterystyka ruchu turystycznego wokół wybranych zbiorników retencyjnych w Polsce. Prace Geograficzne, 121, 87-95.

Dziedzic, E., Skalska, T. (2012). Ekonomiczne uwarunkowania rozwoju ustug turystycznych w Polsce. Warszawa: Stowarzyszenie na rzecz Badania, Rozwoju i Promocji Turystyki.

Fundusze unijne dla przedsiębiorstw w latach 2014-2020. (2020, 26 kwietnia). Pozyskano z: https://mojafirma.infor.pl/fundusze-unijne/dotacje/699838,Fundusze-unijne-dla-przedsiebiorstw-w-latach-2014-2020-r.html

Fundusze unijne na lata 2014-2020. (2020, 25 kwietnia). Pozyskano z: https://pg.edu.pl/dzial-projektow/ fundusze-unijne-na-lata-2014-2020

Gołembski, G. (red.). (2007). Przedsiębiorstwo turystyczne. Ujęcie statyczne i dynamiczne. Warszawa: Polskie Wydawnictwo Ekonomiczne.

GUS. Bank Danych Lokalnych. (2018, 4 marca). Pozyskano z: https://bdl.stat.gov.pl/BDL/dane/podgrup/tablica

Jarmołowicz, W., Knapińska, M. (2005). Polityka państwa na rynku pracy w warunkach transformacji i integracji gospodarczej. Poznań: Wydawnictwo Akademii Ekonomicznej w Poznaniu.

Kaja, J. (2007). Polityka gospodarcza. Wstęp do teorii. Warszawa: Szkoła Główna Handlowa.

Kobyłka, A., Mazurek-Kusiak, A. (2017). Polityka turystyczna województwa lubelskiego realizowana przez urząd marszałkowski. Ekonomiczne Problemy Turystyki, 3(39), 101-113.

Koniunktura gospodarcza. (2020, 25 kwietnia). Pozyskano z: https://businessinsider.com.pl/koniunktura-gospodarcza

Kotler, P., Armstrong, G.A. (1989). Principles of Marketing. London: Prentice-Hall.

Kowalczuk, A. (2015). Otoczenie przedsiębiorstwa jako determinanta konkurencyjności. Przedsiębiorstwo i Region, 7, 38-52.

Kucharenko, K. (2017). Assesment of impact of global business environment of international tourism brands. EUREKA: Social and Humanities, 4, 21-36.

Kulieshova, N.V. (2014). Factor model of the significant factors in the macro environment of tourism enterprises. Проблеми Економіки, 3, 246-254.

Lijewski, T., Mikułowski, B., Wyrzykowski, J. (2002). Geografia turystyki Polski. Warszawa: PWE.

Łoś-Nowak, T. (red.). (1997). Współczesne stosunki międzynarodowe. Wrocław: Wydawnictwo Uniwersytetu Wrocławskiego.

Mekinc, J., Cvikl, H. (2013). The structure of security and safety crises in tourism. Journal of Tourism \& Services, 4(5/6), 38-50. 
Michalski, R. (1990). Cele polityki gospodarczej. W: H. Bąk, Z. Marciniak, R. Michalski, D. Rosati (red.), Wstęp do polityki gospodarczej. Warszawa: Instytut Koniunktur i Cen Handlu Zagranicznego, $10-14$.

Molo, B. (2018). Stosunki międzynarodowe - pojęcie, zakres oraz forma z perspektywy wybranych teorii i podejść badawczych. Krakowskie Studia Międzynarodowe, 3(XV), 13-28.

MŚP i fundusze Unii Europejskiej. Przewodnik beneficjenta po programach operacyjnych $w$ perspektywie finansowej 2014-2020. (2015). Pozyskano z: https://www.fund.org.pl/plik,3484,msp-i-fundusze-unii-europejskiej-przewodnik-beneficjenta-po-programach-operacyjnych-w-perspektywie-finansowej-2014-2020-pdf.pdf

Nizard, G. (1998). Metafory przedsiębiorstwa. Zarządzanie w zmiennym otoczeniu organizacji. Warszawa: PWN.

Nowakowski, M.K. (red.). (2000). Biznes międzynarodowy - obszary decyzji strategicznych. Warszawa: Wydawnictwo Key Text.

Panasiuk, A. (2014). Determinanty i modele kształtowania roli państwa w gospodarce turystycznej. Zeszyty Naukowe Polskiego Towarzystwa Ekonomicznego, 16, 159-175.

Panasiuk, A. (2016). Polityka Unii Europejskiej w oddziaływaniu na wielkość i strukturę popytu turystycznego. Współczesne Problemy Ekonomiczne, 13, 113-122.

Panasiuk, A. (2019). Ocena zmian w makrootoczeniu funkcjonowania współczesnego biznesu turystycznego. Rozprawy Naukowe Akademii Wychowania Fizycznego we Wrocławiu, 64, 11-22.

Penc, J. (2003). Zarzadzanie w warunkach globalizacji. Warszawa: Difin.

Pfetsch, F.R. (1994). Internationale Politik. Stuttgart: Kohlhammer.

Piwowarczyk, A. (2017). Fundusze unijne jako źródło finansowania przedsiębiorczości. W: R. Blicharz (red.), Przedsiębiorca: zagadnienia wybrane. Katowice: Wydawnictwo Uniwersytetu Śląskiego, 321-346.

Polus, A. (2018). Znaczenie teorii stosunków międzynarodowych. W: Ł. Fijałkowski, R. KunertMilcarz (red.), Międzynarodowe stosunki polityczne. Wrocław: Wydawnictwo Uniwersytetu Wrocławskiego, 43-61.

Pytel, S., Szromek, A. (2012). Charakterystyka ruchu turystycznego jako miara rozwoju popytu turystycznego - przykład ruchu turystycznego wybranych parków krajobrazowych. Ekonomiczne Problemy Ustug, 84, 109-122.

Sijabat, R. (2019). Macro-environment analysis of the tourism industry in Indonesia: findings from the PEST analysis. Innovative issues and approaches in social sciences, 12(3), 96-118.

Taylor, E. (1947). Wstęp do ekonomiki. Gdynia: Spółdzielnia Wydawnicza „Żeglarz”.

Urząd Statystyczny w Lublinie. (2018). Turystyka w województwie lubelskim w 2017 r. Lublin: Urząd Statystyczny.

Wodejko, S. (1998). Ekonomiczne zagadnienia turystyki. Warszawa: Wyższa Szkoła Handlu i Prawa.

Wolański, R. (2013). Wplyw otoczenia finansowego na konkurencyjność małych i średnich przedsiębiorstw. Warszawa: Wolters Kluwer Business.

Zygmunt, A., Zygmunt, J. (red.). (2016). Dostosowanie przedsiębiorstw do zmian otoczenia zewnętrznego. Opole: Politechnika Opolska.

Żurek, J. (red.). (2003). Ekonomika i kierowanie rozwojem przedsiębiorstwa. Gdańsk: Fundacja Rozwoju Uniwersytetu Gdańskiego.

Marek Kuźmicki, dr, adiunkt na Wydziale Nauk Ekonomicznych w Państwowej Szkole Wyższej im. Papieża Jana Pawła II w Białej Podlaskiej. Autor 70 artykułów publikowanych w czasopismach naukowych i pracach zbiorowych. Jego publikacje koncentrują się na analizie instytucjonalno-systemowych uwarunkowań rozwoju przedsiębiorstw świadczących usługi noclegowe i gastronomiczne.

Marek Kuźmicki, PhD, assistant professor at the Faculty of Economic Sciences at Pope John Paul II State School of Higher Education in Biała Podlaska. Author of 70 articles published in scientific journals and collective works. His publications focus on the institutional and system analysis of the conditions for the development of enterprises providing accommodation and catering services. 
Pożądane zmiany w otoczeniu międzynarodowym a rozwój...

ORCID: https://orcid.org/0000-0002-0581-9600

\section{Adres/Address:}

Państwowa Szkoła Wyższa im. Papieża Jana Pawła II w Białej Podlaskiej

Wydział Nauk Ekonomicznych

ul. Sidorska 95/97

21-500 Biała Podlaska, Poland

e-mail: m.kuzmicki@dydaktyka.pswbp.pl 